\title{
Application of FT-IR spectroscopy to assess physiological stress in rugby players during fatigue test
}

\author{
Paulo Cesar Caetano Júnior*, Lia Campos Lemes, Josafá Carvalho Aguiar, Juliana Ferreira Strixino,
} Leandro Raniero

\begin{abstract}
Introduction: The diagnosis based on salivary biomarkers provides information about the physiological condition. However, the clinical trials used to analyze these biomarkers are relatively expensive and laborious. Thus, the purpose of this study was to identify the physiological stress in players using Fourier transform infrared spectroscopy (FT-IR). Methods: Thirteen male rugby players were submitted to the treadmill fatigue test and saliva collections were performed before and immediately after test. The FT-IR spectra of saliva samples were analyzed by the second derivative and cluster analysis. Results: From the results of cluster analysis were possible to discriminate the spectra of saliva before and after physical effort using the spectral region between 1490 to $1420 \mathrm{~cm}^{-1}$. Only the saliva spectra from two players were not discriminated in pre-exercise group and post-exercise group, which are in agreement with lowest value of heart rates. Conclusion: The second derivative showed differences between the average spectra of saliva samples collected pre and post-test, which explain the spectra discrimination by the cluster analysis using a specific infrared region for the identification of physiological stress.
\end{abstract}

Keywords: Infrared spectroscopy, Saliva, Sports.

\section{Introduction}

The competitive training of athletes provides the training loads that are effective for performance improvement. This process requires successful interaction between the training load and recovery time, since failures in this process may promote overreaching and overtraining, resulting in some cases maladaptations and diminished competitive performance (Meeusen et al., 2013).

The diagnosis based on saliva provides information about the physiological condition, which has some advantages like low contamination risk and non-invasive procedure (Al-Shehri et al., 2013; Chiappin et al., 2007). Thus, several studies have utilized saliva analysis as a tool for monitoring steroid, peptide, and immune markers of sports training (Papacosta and Nassis, 2011; Papacosta et al., 2013). However, the clinical trials used to analyze salivary biomarkers (Al-Shehri et al., 2013; Moreira et al., 2013; Novaković et al., 2013; Salazar et al., 2013) are relatively expensive and laborious, which decreases the number of teams using this technology.

Fourier-transform infrared spectroscopy (FT-IR) has also been used to characterize biological samples as an alternative technique for laboratory tests (Ellis and Goodacre, 2006; Khaskheli et al., 2013).
This technique has great potential for analysis of body fluids (Petibois et al., 2000; Yoshida et al., 2013), allowing quantifying the biochemical components of biological sample. This quantification is done through the infrared absorption spectrum in the spectral range of $4000-700 \mathrm{~cm}^{-1}$, which is related to the vibrational modes of molecular radicals (Schultz et al., 1996). It also has some advantages compare to these laboratories analysis, such as easy sample preparation for spectral acquisition, it requires a small volume of sample and no further reagents (Franck et al., 1998; Khaustova et al., 2010; Petibois et al., 2000).

There are few works with FT-IR spectroscopy applied to saliva in the sport area, but it have shown promising results with quantitative analysis of biochemical components and provided real-time information (Khaustova et al., 2010; Perez-Guaita et al., 2012). Some spectral bands of saliva were identified in the infrared region for biochemical components such as, cortisol, phosphate, glucose, protein, urea and SIgA. In addition, the levels of cortisol obtained by clinical laboratory trials have been correlated to IR bands of the saliva spectra (Khaustova et al., 2010).

In our previous work, the homogenization of saliva samples by vigorous mixing were the most 
appropriated way for FT-IR measurements, which was used mainly to classify the physiological status of athletes in exercise training by FT-IR (Caetano et al., 2015). In this context, the purpose of this study was to discriminate FT-IR spectra of mixed saliva collected before and after fatigue test continued, using cluster analysis.

\section{Methods}

\section{Participants}

This study was approved by the Ethics Research Committee of the University of Vale of Paraiba (No. 255.474) and all athletes were volunteers. The group was composed of 13 male rugby players (Age: $19 \pm 1$ years; Height: $174 \pm 6 \mathrm{~cm}$; Weight: $77.2 \pm 12.2 \mathrm{~kg}$ ). The exclusion criteria were: use drugs/tobacco, existence of oral disease and any type of physical injury. Thus, the saliva samples of two players (R9 and R10) were excluded.

\section{Fatigue protocol}

The fatigue test was performed on a treadmill (Movement LX 150). First, the subjects performed warm-up on the treadmill for 5 min at speed of $7 \mathrm{~km} / \mathrm{h}$. The players were required to run at $9 \mathrm{~km} / \mathrm{h}$ for $5 \mathrm{~min}$, and then followed by $1 \mathrm{~km} / \mathrm{h}$ speed increments every 2 min until achieving fatigue (Quammen et al., 2012). At this point, the subjects were instructed to signal with his arm and the speed was slowed down to a walk. Measurements of resting and exercise heart rates (HR), during the entire test were performed with a heart rate monitor (model FT1, Polar Electro).

\section{Saliva collection}

Saliva collection was performed at 7:00 am, before and immediately after fatigue test. All subjects were informed in advance to abstain from food and caffeine products for at least $2 \mathrm{~h}$ prior to the saliva collection. They were instructed to rinse out their mouths with distilled water and remain seated with eyes open, head tilted slightly forward, and avoid orofacial movements (Chiappin et al., 2007; Moreira et al., 2013). Unstimulated saliva samples were collected in sterilized tubes of $2 \mathrm{ml}$ for approximately $10 \mathrm{~min}$ per athlete. The samples were immediately refrigerated at $5^{\circ} \mathrm{C}$, centrifuged at $1700 \mathrm{~g}$ for $10 \mathrm{~min}$ (Thermo Scientific $^{\mathrm{TM}}$ Heraeus $^{\mathrm{TM}}$ Multifuge ${ }^{\mathrm{TM}} \mathrm{X} 1$ Centrifuge Series) and stored at $-20^{\circ} \mathrm{C}$ until FT-IR measurements.

\section{Saliva analysis by FT-IR}

Defrosted samples were homogenized for $10 \mathrm{~s}$ at full speed for $15 \mathrm{~s}$ using a mixer X(MS2; Minishaker Ika-Works Inc., Wilmington, NC, USA). After this process, $15 \mu \mathrm{l}$ of saliva was deposited on a calcium fluoride $\left(\mathrm{CaF}_{2}\right)$ window and dried for 60 min using an incubator (Quimis, Q317B-53, Brazil).

Infrared spectra were collected by a Spectrum 400 spectrophotometer coupled to a microscope (Perkin-Elmer, Spotlight 400) controlled by a computer using Spotlight 400 Software. Spectra were recorded in the spectral region 4000 to $750 \mathrm{~cm}^{-1}$, with 32 scans and a spectral resolution of $4 \mathrm{~cm}^{-1}$. The measurements were performed along the thin film, formed on the $\mathrm{CaF}_{2}$ surface, in eight random points (Caetano et al., 2015). A total of 240 spectra were obtained in two different experimental times (Pre and post physical effort).

\section{Statistical analyses}

The means and standard deviation (SD) of the data were calculated. FT-IR spectra of saliva samples were analyzed by OPUS software (version 4.2) using cluster analysis and the following parameters: second derivative, smoothing 9 points, Ward's algorithm, and scaling to 1 st range method. Cluster analysis classifies objects into groups which show similarities (Hair et al., 1998). In this study, this analysis was performed using the spectral region between $1490-1420 \mathrm{~cm}^{-1}$ to discriminate saliva spectra collected before and after physical effort.

\section{Results}

Exercise intensity during fatigue test was verified by HR, as shown in the Figure 1A. The Figure 1B shows the average $\mathrm{HR}$ values (SD) that were obtained from 5 min per players and HRmax (\%), where the peak HR attained at exhaustion of maximal graded exercise was considered as HRmax (Galy et al., 2014). The results shows eleven players with similar HR mean values, except for R7 and R11 players that showed lower mean values.

The average of the FT-IR saliva spectra from samples collected before and after treadmill fatigue test are shown in the Figure 2. The region highlighted $\left(1490-1420 \mathrm{~cm}^{-1}\right)$ was used in the cluster analysis.

The results from cluster analysis are shown in the Figure 3. This analysis was performed using the spectral region between $1490-1420 \mathrm{~cm}^{-1}$, which permitted to discriminate saliva spectra collected before and after treadmill test, as shown in the dendrogram. This discrimination shows that spectra of saliva collected at rest and under stress had different absorption bands. Only saliva spectra R7 and R11 players were not discriminated in pre-exercise group and post-exercise group, which show that physiological stress levels these players were lower as found in HR results. 
A)

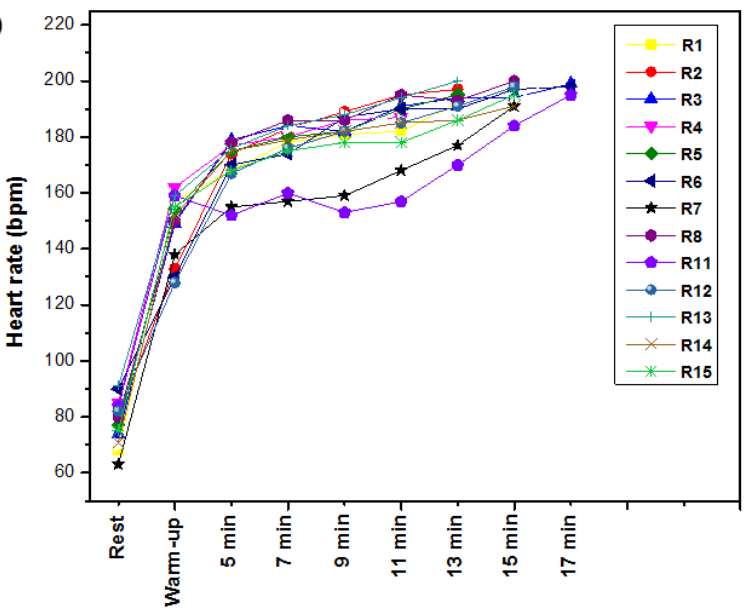

B)

\begin{tabular}{|c|c|c|}
\hline Players & $\begin{array}{c}\text { HR mean } \\
\text { values } \mathbf{\text { SD }} \\
\text { (bpm) }\end{array}$ & \% of HRmax \\
\hline R1 & $180 \pm 8$ & $93 \pm 4$ \\
\hline R2 & $187 \pm 9$ & $95 \pm 4$ \\
\hline R3 & $186 \pm 6$ & $93 \pm 3$ \\
\hline R4 & $182 \pm 5$ & $96 \pm 2$ \\
\hline R5 & $184 \pm 8$ & $94 \pm 4$ \\
\hline R6 & $182 \pm 9$ & $91 \pm 4$ \\
\hline R7 & $163 \pm 9$ & $96 \pm 1$ \\
\hline R8 & $187 \pm 6$ & $93 \pm 3$ \\
\hline R11 & $158 \pm 7$ & $89 \pm 3$ \\
\hline R12 & $180 \pm 9$ & $90 \pm 4$ \\
\hline R13 & $188 \pm 9$ & $94 \pm 4$ \\
\hline R14 & $181 \pm 4$ & $95 \pm 2$ \\
\hline R15 & $180 \pm 9$ & $92 \pm 4$ \\
\hline
\end{tabular}

Figure 1. Heart rate of the players, during treadmill fatigue test. (A) Heart rate values measured continuously in each stage; (B) HR mean values (SD) obtained from 5 min and HRmax (\%) per players $(\mathrm{n}=13)$.

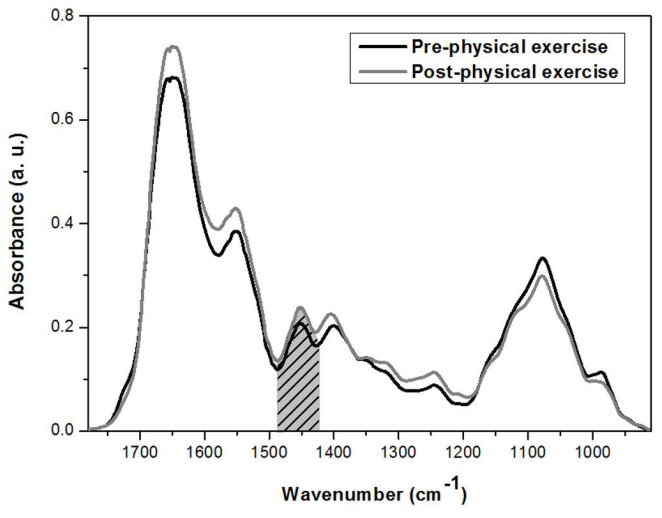

Figure 2. Average FT-IR spectra recorded in $1800-900 \mathrm{~cm}^{-1}$ region for saliva samples collected before and after test.

The Figure 4A shows the average spectra of saliva samples in the region $1490-1420 \mathrm{~cm}^{-1}$ and the arrows the bands revealed by second derivative calculation, as shown in Figure 4B. These results show the main differences between the spectra of saliva collected before and after physical effort.

\section{Discussion}

In this study, the treadmill fatigue protocol was used to obtain the diagnosis of physiological stress through the saliva analysis by FT-IR. The exercise intensity was monitored by HR, which has been shown to be a good indicator of the exercise intensity (Chamari et al., 1995; 2004).

The HR values showed the exercise intensity was hard because according to the American College of
Sports Medicine Position Stand (Pollock et al., 1998) HR values above $70 \%$ peak HR can be considered hard-to-very hard. R7 and R11 players showed lower mean values due to a better aerobic capacity than the others players. These results could be explained by the individuals performance and sports training (Burini et al., 2010; Galy et al., 2014).

The results obtained by FT-IR using cluster analysis possible to discriminate the spectra of saliva collected before and after physical effort. The players that had the lowest HR values, also the spectra were in the pre-exercise groups. These findings shows the HR can be influenced by increased stress, which was previously shown in other studies (Galosy et al., 1981; Sapolsky et al., 2000).

This influence can be explained by certain levels of cortisol are necessary for the catecholamines and other sympathetic products to exert effects on the cardiovascular system, for example, induce vasoconstriction and increase heart rate. Thus, the specific conditions that elevate cortisol concentrations also have the potential to influence the variety of critical physiological processes that can be affected by hypothalamic-pituitary-adrenocortical axis activity (Dickerson and Kemeny, 2004). In this study, saliva collection was performed at 7:00 am, due to salivary cortisol circadian rhythm, in which levels increase dramatically on awakening and gradually decrease throughout the day, reaching the lowest levels late in the evening (Faghih et al., 2015).

It is important to highlight that saliva samples were homogenized because recently we show this process is important to avoid loss of certain proteins that can precipitate after saliva-defrosting process and 


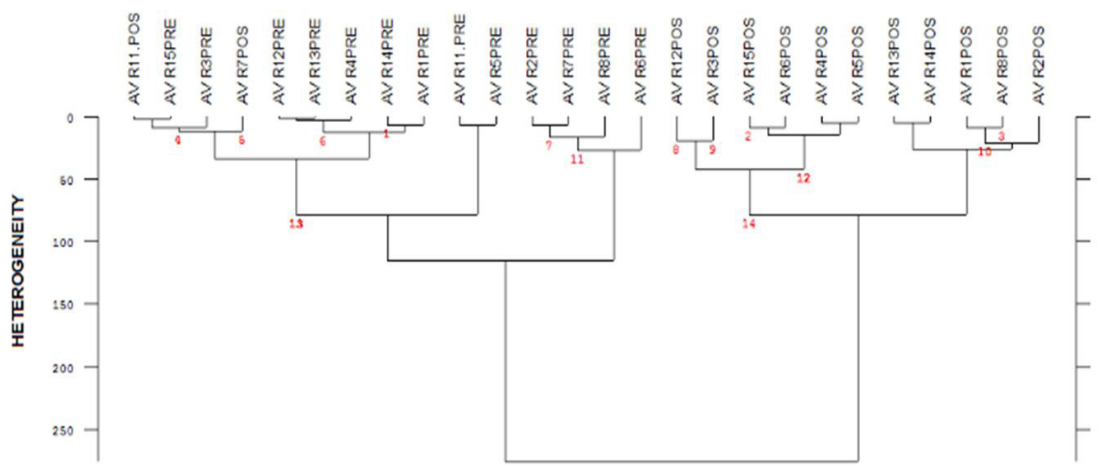

Figure 3. The dendrogram indicates the difference between the saliva samples collected pre and post physical effort in region $1490-1420 \mathrm{~cm}^{-1}$. Saliva spectra R7 and R11 players were not discriminated in pre-exercise group and post-exercise group. Cluster analysis used the second derivate, smoothing 9 points, Ward's algorithm and scaling to 1st range method for classifying objects into groups showing similarities.
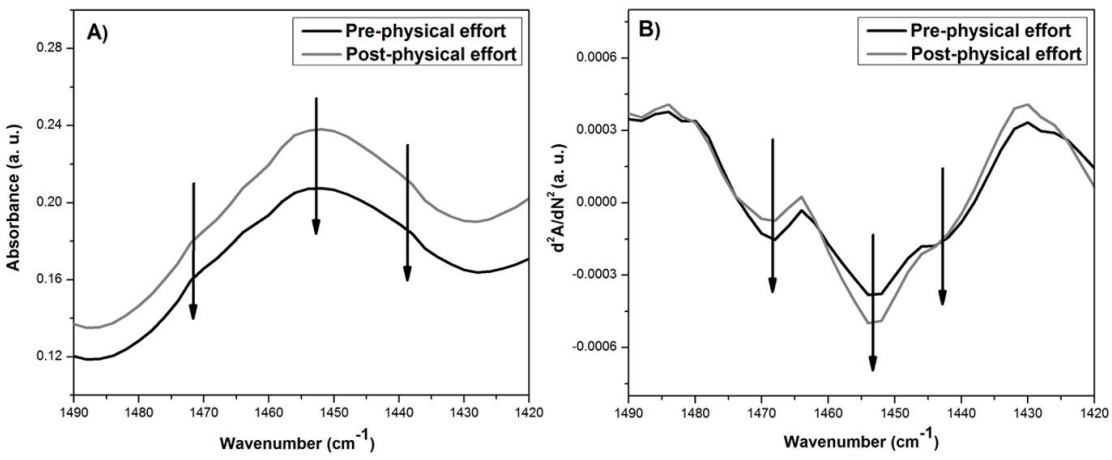

Figure 4. Saliva samples spectra collected pre and post-test. (A) Identification of the main bands in average spectra of saliva pre and post-test; (B) Second derivative of the average spectra of saliva samples collected pre and post-test.

most effective way to classify physiological stress in athletes. The importance of the homogenization process of saliva samples was done by the main biochemical differences between supernatant and precipitate from saliva, which showed the combo (precipitate plus supernatant) is the most appropriate way to discriminate spectra of saliva collected before and after physical effort by multivariate statistical analysis (Caetano et al., 2015).

This discrimination of the saliva spectra (pre and post treadmill fatigue test) was done using the spectral region 1490-1420 $\mathrm{cm}^{-1}$, which correspond to the vibrational modes of $\mathrm{C}-\mathrm{H}$ deformation of $>\mathrm{CH}_{2}, \mathrm{CH}_{3}$ asymmetric bending, $\mathrm{C}=\mathrm{O}$ symmetric stretching of COO- group in aminoacids/fatty acids (Beekes et al., 2007; Khaustova et al., 2010; Krimm and Bandekar, 1986; Naumann, 2006; Oberg et al., 2004; Stuart, 1997). Thus, this region can be attributed to cortisol due to their chemical structure $\mathrm{C}_{21} \mathrm{H}_{30} \mathrm{O}_{5}$, as well as that others salivary biomarkers (e.g., immunoglobulin A, $\alpha$-amylase, testosterone, etc.) that can have similar vibrational modes, which are also changed in response to physical effort, as shown by Khaustova et al. (2010).

Although saliva contains a large number of protein compounds and hormones (Chiappin et al., 2007; Humphrey and Williamson, 2001), some studies found correlation between absorption bands with measurements of salivary components concentrations using others laboratory techniques and methods. These findings show that some salivary components, such as cortisol, immunoglobulin A, $\alpha$-amylase and total protein, has specific bands in infrared region (Khaustova et al., 2009; 2010). In addition, whole saliva contains mainly water, which would also be a limiting factor of the technique. However, this disadvantage is easily corrected using process of dehydration or subtracting the signal water (Petibois et al., 2000).

The second derivative of FT-IR spectra of the saliva samples using region $1490-1420 \mathrm{~cm}^{-1}$, it is possible to identify the differences between the spectra 
of saliva collected before and after treadmill fatigue test. In the same region, it observed three important bands in 1470,1453 and $1441 \mathrm{~cm}^{-1}$, which help to explain the discrimination of the spectra of saliva pre and post exercise, as well as identify a region (1490-1420 $\left.\mathrm{cm}^{-1}\right)$ of high specificity for determine the physiological stress.

This spectral discrimination during training shows that there important changes of salivary biomarkers for specific athlete, serving as parameter for coaches. It is suggested that the spectra obtained in pre-season training should be used as group-rest parameters for comparisons of saliva spectra collected during the preparation and pre-competitive training periods. Thus, the athlete classified as stressed by FT-IR spectroscopy, should be subjected to additional analysis to ensure the state of stress of this athlete (e. g., physical tests and blood laboratory tests).

The results obtained in this study show the powerful diagnostic FT-IR to identify physiological stress. In addition, FT-IR spectroscopy does not require large volumes of sample and provided real-time information without the use of reagents. Thus, monitoring of physiological stress in athletes that belong to teams without financial support is possible to avoid overtraining syndrome, which can compromise the health and performance of these players.

In conclusion, it was possible to discriminate spectra of saliva collected before and after physical effort into two groups, using cluster analysis. This discrimination was performed by an infrared region with high specificity for the identification of stress.

\section{Acknowledgements}

The authors would like to thank the financial support of CNPQ (Project 470534/2012-5) and CAPES

\section{References}

Al-Shehri S, Henman M, Charles BG, Cowley D, Shaw PN, Liley H, Tomarchio A, Punyadeera C, Duley JA. Collection and determination of nucleotide metabolites in neonatal and adult saliva by high performance liquid chromatography with tandem mass spectrometry. Journal of Chromatography B: Analytical Technologies in the Biomedical and Life Sciences. 2013; 931:140-7. http://dx.doi.org/10.1016/j. jchromb.2013.05.001. PMid:23792366.

Beekes M, Lasch P, Naumann D. Analytical applications of Fourier Transform-Infrared (FT-IR) spectroscopy in microbiology and prion research. Veterinary Microbiology. 2007; 123(4):305-19. http://dx.doi.org/10.1016/j. vetmic.2007.04.010. PMid:17540519.
Burini FHP, Oliveira EP, Burini RC. (Mal) adaptações metabólicas ao treinamento contínuo: concepções não consensuais de terminologia e diagnóstico. Revista Brasileira de Medicina do Esporte. 2010; 16(5):388-92. http://dx.doi. org/10.1590/S1517-86922010000500014

Caetano PC Jr, Strixino JF, Raniero L. Analysis of saliva by Fourier transform infrared Spectroscopy for diagnosis of physiological stress in athletes. Research on Biomedical Engineering. 2015; 31(2):116-24. http://dx.doi. org/10.1590/2446-4740.0664.

Chamari K, Ahmaidi S, Fabre C, Ramonatxo M, Prefaut C. Pulmonary gas exchange and ventilatory responses to brief intense intermittent exercise in young trained and untrained adults. European Journal of Applied Physiology. 1995; 70(5):442-50. http://dx.doi.org/10.1007/BF00618496. PMid:7671880.

Chamari K, Hachana Y, Ahmed YB, Galy O, Sghaier F, Chatard JC, Hue O, Wisloff U. Field and laboratory testing in young elite soccer players. British Journal of Sports Medicine. 2004; 38(2):191-6. http://dx.doi.org/10.1136/ bjsm.2002.004374. PMid:15039258.

Chiappin S, Antonelli G, Gatti R, De Palo EF. Saliva specimen: a new laboratory tool for diagnostic and basic investigation. Clinica Chimica Acta. 2007; 383(1-2):30-40. http://dx.doi.org/10.1016/j.cca.2007.04.011. PMid:17512510.

Dickerson SS, Kemeny ME. Acute stressors and cortisol responses: a theoretical integration and synthesis of laboratory research. Psychological Bulletin. 2004; 130(3):355-91. http:// dx.doi.org/10.1037/0033-2909.130.3.355. PMid:15122924

Ellis DI, Goodacre R. Metabolic fingerprinting in disease diagnosis: biomedical applications of infrared and Raman spectroscopy. Analyst. 2006; 131(8):875-85. http://dx.doi. org/10.1039/b602376m. PMid:17028718.

Faghih RT, Dahleh MA, Brown EN. An optimization formulation for characterization of pulsatile cortisol secretion. Frontiers in Neuroscience. 2015; 9:228. http:// dx.doi.org/10.3389/fnins.2015.00228. PMid:26321898.

Franck P, Nabet P, Dousset B. Applications of infrared spectroscopy to medical biology. Cellular and Molecular Biology. 1998; 44(2):273-5. PMid:9593577.

Galosy RA, Clarke LK, Vasko MR, Crawford IL. Neurophysiology and neuropharmacology of cardiovascular regulation and stress. Neuroscience and Biobehavioral Reviews. 1981; 5(1):137-75. http://dx.doi.org/10.1016/01497634(81)90040-3. PMid:7015187.

Galy O, Ben Zoubir S, Hambli M, Chaouachi A, Hue $\mathrm{O}$, Chamari K. Relationships between heart rate and physiological parameters of performance in top-level water polo players. Biology of Sport. 2014; 31(1):33-8. http:// dx.doi.org/10.5604/20831862.1083277. PMid:24917687.

Hair JFA, Rolph E, Tatham RL. Multivariate data analysis. 7th ed. New Jersey: Prentice Hall; 1998.

Humphrey SP, Williamson RT. A review of saliva: normal composition, flow, and function. The Journal of Prosthetic Dentistry. 2001; 85(2):162-9. http://dx.doi.org/10.1067/ mpr.2001.113778. PMid:11208206.

Khaskheli AR, Sirajuddin, Sherazi STH, Mahesar SA, Kandhro AA, Kalwar NH, Mallah MA. Estimation of ibuprofen 
in urine and tablet formulations by transmission Fourier Transform Infrared spectroscopy by partial least square. Spectrochimica Acta Part A: Molecular and Biomolecular Spectroscopy. 2013; 102:403-7. http://dx.doi.org/10.1016/j. saa.2012.10.021.

Khaustova S, Shkurnikov M, Tonevitsky E, Artyushenko V, Tonevitsky A. Noninvasive biochemical monitoring of physiological stress by Fourier transform infrared saliva spectroscopy. Analyst. 2010; 135(12):3183-92. http://dx.doi. org/10.1039/c0an00529k. PMid:20953513.

Khaustova SA, Shkurnikov MU, Grebenyuk ES, Artyushenko VG, Tonevitsky AG. Assessment of biochemical characteristics of the saliva using Fourier transform mid-infrared spectroscopy. Bulletin of Experimental Biology and Medicine. 2009; 148(5):841-4. http://dx.doi.org/10.1007/s10517-010-08315. PMid:20396807.

Krimm S, Bandekar J. Vibrational spectroscopy and conformation of peptides, polypeptides, and proteins. Advances in Protein Chemistry. 1986; 38:181-364. http:// dx.doi.org/10.1016/S0065-3233(08)60528-8. PMid:3541539.

Meeusen R, Duclos M, Foster C, Fry A, Gleeson M, Nieman D, Raglin J, Rietjens G, Steinacker J, Urhausen A. Prevention, diagnosis, and treatment of the overtraining syndrome: joint consensus statement of the European College of Sport Science and the American College of Sports Medicine. Medicine and Science in Sports and Exercise. 2013; 45(1):186-205. http://dx.doi.org/10.1249/ MSS.0b013e318279a10a. PMid:23247672.

Moreira A, Freitas CG, Nakamura FY, Drago G, Drago M, Aoki MS. Effect of match importance on salivary cortisol and immunoglobulin A responses in elite young volleyball players. Journal of Strength and Conditioning Research. 2013; 27(1):202-7. http://dx.doi.org/10.1519/ JSC.0b013e31825183d9. PMid:22395269.

Naumann D. Infrared spectroscopy in microbiology. Biomedical Spectroscopy. 2006. In press. http://dx.doi. org/10.1002/9780470027318.a0117.

Novaković N, Cakić S, Todorović T, Raicević BA, Dozić I, Petrović V, Perunović N, Gostović SS, Sretenović JK, Colak E. Antioxidative status of saliva before and after nonsurgical periodontal treatment. Srpski Arhiv za Celokupno Lekarstvo. 2013; 141(3-4):163-8. http://dx.doi.org/10.2298/ SARH1304163N. PMid:23745337.

Oberg KA, Ruysschaert JM, Goormaghtigh E. The optimization of protein secondary structure determination with infrared and circular dichroism spectra. European Journal of Biochemistry. 2004; 271(14):2937-48. http://dx.doi. org/10.1111/j.1432-1033.2004.04220.x. PMid:15233789.

Papacosta E, Gleeson M, Nassis GP. Salivary hormones, $\mathrm{IgA}$ and performance during intense training and tapering in judo athletes. Journal of Strength and Conditioning Research. 2013; 27(9):2569-80. http://dx.doi.org/10.1519/ JSC.0b013e31827fd85c. PMid:23249825.
Papacosta E, Nassis GP. Saliva as a tool for monitoring steroid, peptide and immune markers in sport and exercise science. Journal of Science and Medicine in Sport. 2011; 14(5):424-34. http://dx.doi.org/10.1016/j.jsams.2011.03.004. PMid:21474377.

Perez-Guaita D, Ventura-Gayete J, Pérez-Rambla C, Sancho-Andreu M, Garrigues S, de la Guardia M. Protein determination in serum and whole blood by attenuated total reflectance infrared spectroscopy. Analytical and Bioanalytical Chemistry. 2012; 404(3):649-56. http://dx.doi.org/10.1007/ s00216-012-6030-7. PMid:22547354.

Petibois C, Déléris G, Cazorla G. Perspectives in the utilisation of Fourier-transform infrared spectroscopy of serum in sports medicine: health monitoring of athletes and prevention of doping. Sports Medicine. 2000; 29(6):387-96. http://dx.doi.org/10.2165/00007256-200029060-00002. PMid:10870865.

Pollock ML, Gaesser GA, Butcher JD, Despr??s J-P, Dishman RK, Franklin BA, Garber CE. ACSM position stand: the recommended quantity and quality of exercise for developing and maintaining cardiorespiratory and muscular fitness, and flexibility in healthy adults. Medicine and Science in Sports and Exercise. 1998; 30(6):975-91. http://dx.doi. org/10.1097/00005768-199806000-00032. PMid:9624661.

Quammen D, Cortes N, Van Lunen BL, Lucci S, Ringleb SI, Onate J. Two different fatigue protocols and lower extremity motion patterns during a stop-jump task. Journal of Athletic Training. 2012; 47(1):32-41. PMid:22488228.

Salazar MG, Jehmlich N, Murr A, Dhople VM, Holtfreter B, Hammer E, Völker U, Kocher T. Identification of periodontitis associated changes in the proteome of whole human saliva by mass spectrometric analysis. Journal of Clinical Periodontology. 2013; 40(9):825-32. http://dx.doi. org/10.1111/jepe.12130. PMid:23790309.

Sapolsky RM, Romero LM, MunckAU. How do glucocorticoids influence stress responses? Integrating permissive, suppressive, stimulatory, and preparative actions. Endocrine Reviews. 2000; 21(1):55-89. http://dx.doi.org/10.1210/edrv.21.1.0389. PMid:10696570.

Schultz CP, Ahmed MK, Dawes C, Mantsch HH. Thiocyanate levels in human saliva: quantitation by Fourier transform infrared spectroscopy. Analytical Biochemistry. 1996; 240(1):7-12. http://dx.doi.org/10.1006/abio.1996.0323. PMid:8811872.

Stuart B. Biological applications of infrared spectroscopy. Chichester: John Wiley \& Sons; 1997.

Yoshida S, Yoshida M, Yamamoto M, Takeda J. Optical screening of diabetes mellitus using non-invasive Fouriertransform infrared spectroscopy technique for human lip. Journal of Pharmaceutical and Biomedical Analysis. 2013; 76:169-76. http://dx.doi.org/10.1016/j.jpba.2012.12.009. PMid:23333685.

\section{Authors \\ Paulo Cesar Caetano Júnior ${ }^{*}$, Lia Campos Lemes ${ }^{1}$, Josafá Carvalho Aguiar ${ }^{1}$, Juliana Ferreira Strixino ${ }^{1}$, Leandro Raniero $^{1}$ \\ ${ }^{1}$ Laboratório de Nanosensores, Instituto de Pesquisa e Desenvolvimento - IP\&D, Universidade do Vale do Paraíba - UNIVAP, Av. Shishima Hifumi, 2911, CEP 12244-000, São Jose dos Campos, SP, Brazil.}

